\title{
SOCIO-PRAGMATIC PECULIARITIES
}

\section{OF APOLOGY UTTERANCES IN MODERN ENGLISH}

\author{
Olena Botvinko-Botiuk, \\ $\mathrm{PhD}$ in Philology, \\ Assistant Professor of Foreign \\ Languages Department, \\ National University of Water \\ Management and Nature Resources \\ Use, \\ Rivne, Ukraine \\ ane_1ll@ukr.net
}

\author{
Elina Koliada, \\ PhD in Philology, \\ Professor of Conversational English \\ Department, \\ Lesya Ukrainka Eastern European \\ National University, \\ Lutsk, Ukraine \\ eliakoliada@gmail.com
}

Received March, 28, 2018; Accepted April, 27, 2018

\begin{abstract}
In this article, consideration is given to the utterances of apology in Modern English. The utterances of apology belong to the post-event-acts, i.e. they signal that a certain type of event has already taken place. Moreover, the speaker recognizes the fact that a violation of a social norm has been committed and that the speaker is at least partially involved in its cause. The act of apologizing requires an action or an utterance that is intended to "set things right" between the apologizer and the recipient of the apology. The English language provides a range of accepted formulas for apologizing. Utterances of apology can be very short and direct, or longer and more complex. The expression of apology depends on the seriousness and importance of the thing which has happened, the social and cultural standards, the type of situation (official/non-official), the form of apology (written/oral), social relations of the speaker and the hearer (the degree of familiarity), the speaker's feelings, and the degree of the speaker's responsibility for what has happened. There are five possible strategies for making an apology: an expression of an apology, acknowledgement of responsibility, an explanation or account, an offer of repair, and a promise of non-recurrence.
\end{abstract}

Key words: apology, speaker, hearer, speech act, strategy.

\section{Introduction}

In modern linguistics, exploration of social essence of language use (language in action) has been traditionally confined to two main aspects. The first is speech interaction of interlocutors which provides the material for conversational analysis. The second is the interactional nature of utterances viewed in isolation or as a part of sequences of utterances. These facets of language use are studied in speech-act theory, discourse analysis, and text linguistics.

Apologies are social acts. One key to getting along well with people is knowing when and how to apologize. Sometimes little comments or actions can hurt or offend others. Heavy workloads and stress may keep people from seeing how their actions make others feel. The little things can add up. It does not take long for someone to hold a grudge and for grudges to grow into conflicts. In most cases, if someone is 
offended by something you do or say, it is much better to apologize right away. That solves the small problem and keeps it from getting bigger.

The goal of the present paper is to examine socio-pragmatic peculiarities of apology utterances. This goal determined the need to fulfill the following tasks: 1) to study the semantics of apology utterances; 2) to analyze apology as a speech act; 3) to describe the strategies of apology; 4) to define social and contextual factors affecting the apology; 5) to reveal the role of apology in avoiding conflicts.

\section{Making an Apology}

Apology is a statement that tells someone that you are sorry for doing something wrong or causing a problem. An apology can be abject, full, heartfelt, humble, profound, public, and sincere. To apologize means to tell someone that you are sorry for doing something wrong or causing a problem (Macmillan English Dictionary for Advanced Learners, 2004: 54). For example, (1) I apologize for taking so long to reply. Each language provides a range of accepted formulas for apologizing. In the English language they are: Sorry, I'm sorry, I do apologize for..., Excuse me, I owe you an apology, Please accept my/our apologies, I/we regret ..., Please forgive me and others (Razinkina, 2004: 166-169; Formanovskaya \& Shevtsova, 1990: 47-51).

We can apologize in different ways in different situations. When deciding which expressions are suitable for which situations, it is useful to consider the following questions (Slovar sovremennogo angliyskogo yazyka, 1992: 38): 1) How bad is the thing which has happened? If it is very bad, the apology will be stronger; 2) What is the relationship between the person who is apologizing (the speaker) and the person they are speaking to (the hearer)? If the hearer is in a position of authority, the apology may be stronger; 3) How responsible is the speaker for what has happened? If the speaker is really at fault, the apology will be stronger; 4) Will the hearer immediately know the reason for the apology? If not, the speaker must make this clear.

In a social situation as a way of asking someone to forgive you for doing something rude, embarrassing etc. the expression I'm sorry/Sorry! is used: (2) I'm sorry about the misunderstanding; (3) I'm sorry to have kept you waiting, ladies and gentlemen; (4) Sorry I should have phoned to let you know I'd be late (Longman Language Activator, 1996: 1266). I'm sorry is the usual way of apologizing to someone you know well: (5) I'm sorry, I didn't quite hear what she said.

In a formal situation or when saying sorry to someone you do not know well the expression I apologize is used: (6) You were right and I was wrong. I apologize (Longman Language Activator, 1996: 1266). Formal apologies, especially in written form, are often marked by the use of the word apology or apologize: (7) I am writing to apologize for my absence from last week's meeting. I was unexpectedly held up at work and was not able to contact you; (8) Please accept our sincere apologies for any inconvenience caused by the delay in delivery of your order. The goods have now been shipped to you (Slovar sovremennogo angliyskogo yazyka, 1992: 39).

The expression Please accept my/our apologies is used when making a written or formal apology for a mistake or a problem, for example, (9) The replacement should reach you shortly. Please accept my apologies for any inconvenience this error has 
caused; (10) We accept that this was the company's fault and ask you to accept our sincere apologies (Macmillan English Dictionary for Advanced Learners, 2004: 54).

When making an apology in an official announcement the expression I/we regret... is used. For example, (11) We regret to announce that tonight's performance of "La Traviata" has been cancelled; (12) I regret to inform you that you have not been selected for interview (Macmillan English Dictionary for Advanced Learners, 2004: 1188).

I owe you an apology is used when you have done something that you later find out to be wrong or unfair, or when you realize you have treated someone badly, e.g. by blaming them for something that is not their fault: (13) We've discovered who the thief was, and it seems we owe you an apology; (14) I owe you an apology for what I said. I'm afraid I was rather emotional.

When apologizing for something you did accidentally, the expression Excuse $m e$ is used (Slovar sovremennogo angliyskogo yazyka, 1992: 352). For example, (15) Oh, excuse me, I didn't see you standing there. In British English Excuse me is limited to mild apologies for routine impolite behaviour (Lich and Svartvik, 1983: 136). It is used:

- for showing you are sorry because your body has made a rude noise, e.g. sneezing;

- for politely asking someone to move so that you can get past them, Excuse $m e$ (= I would like to go past) (Cambridge International Dictionary of English, 1995: 478). If you have accidentally touched or pushed someone you can say Pardon me (Slovar sovremennogo angliyskogo yazyka, 1992: 746). The expression I beg your pardon is used for saying you are sorry because you have made a slight mistake, e.g. because you have stood on someone's foot. "Sorry" is a less formal way of saying this (Macmillan English Dictionary for Advanced Learners, 2004: 111): (16) Oh, I beg your pardon I didn't realize this was your chair;

- for politely telling someone you are leaving: (17) Excuse me for a momentI have to make a phone call;

- for politely getting someone's attention (Macmillan English Dictionary for Advanced Learners, 2004: 479): (18) Excuse me, do you know what time it is?;

- for showing you are sorry for interrupting someone (Lich and Svartvik, 1983 : 136): (19) Excuse me, but there's a phone call for you. In this case Pardon can be used as well: (20) Pardon me interrupting, but there's a client to see you (Cambridge International Dictionary of English, 1995: 1025). For politely interrupting someone, especially to ask them a question the expression I'm sorry/Sorry! is used: (21) Sorry, do you know the time? (22) I'm sorry for the intrusion, but you have a phone call.

I'm sorry/Sorry! is used for interrupting yourself to correct a mistake you have made while speaking: (23) You need to catch the number 3, sorry, the number 23 bus to Market Street (Macmillan English Dictionary for Advanced Learners, 2004: 13651366).

When you want to ask someone to repeat something because you did not hear or did not understand them you can use the following expressions: I beg your pardon, Pardon?, I'm sorry/Sorry?, and Excuse me. I beg your pardon is used in a formal way. Here is an example:

(24) - Are you ready to leave? 
- I beg your pardon?

- I was just asking if you are ready to leave.

"Pardon?" or "Sorry?" are less formal ways of saying this (Macmillan English Dictionary for Advanced Learners, 2004: 111):

(25) - I'm cold.

- Sorry?

- I said I was cold (Slovar sovremennogo angliyskogo yazyka, 1992: 1006).

(26) I'm sorry what was your name again? (Macmillan English Dictionary for Advanced Learners, 2004: 1365).

In American English Excuse me is used for asking someone to repeat something:

(27) - How old are you?

- Excuse me?

British people say Excuse me before interrupting or disturbing somebody, and Sorry after doing so. Americans also use Excuse me to apologize after disturbing somebody (Swan, 1997: 544).

The expressions Excuse me, I'm sorry/Sorry! and Pardon me are used for politely disagreeing with someone, with someone's opinion and with what someone has said: (28) Excuse me, but I never said I'd pay for everything; (29) I'm sorry, but I don't see how you expect us to finish by lunchtime; (30) Pardon me, but those numbers aren't right (Macmillan English Dictionary for Advanced Learners, 2004: 479, 1366, 1029).

I beg your pardon is used for showing that you disagree very strongly with what someone has just said:

(31) - Jenny doesn't concentrate when she's driving.

- I beg your pardon! She is a very good driver (Macmillan English Dictionary for Advanced Learners, 2004: 111).

I'm sorry to say/report is used for talking about something bad or disappointing that has happened: (32) We're going to have to lay off 100 employees, I'm sorry to say.

The expression I'm sorry/Sorry! is used for telling someone you are ashamed or unhappy about something you have done that has hurt or upset them: (33) I'm sorry, I didn't mean to upset you; (34) I'm sorry - I shouldn't have blamed you; (35) Sorry I didn't mean to step on your foot (Longman Language Activator, 1996: 1266, 1365). The verb to regret has a similar meaning. It means: 1) to feel sorry or sad that something has happened: (36) We regret any inconvenience caused by the delay; 2) to feel sorry or sad about something you have said or done: (37) I deeply regret what happened - there is no excuse for it (Macmillan English Dictionary for Advanced Learners, 2004: 1188).

The expression Forgive me is used when you have done something wrong or have upset someone, or when you are going to say or ask something that might seem rude or offensive. For example, (38) Forgive me, I didn't mean to offend you. Forgive me for asking, but how old are you? (Longman Language Activator, 1996: 1266).

To summarize all said above we state that apology is an act of saying sorry. It shows awareness of and caring for other people's feelings. It reveals socially correct speaker's behaviour. 
The expression of apology depends on the seriousness and importance of the thing which has happened, the social and cultural standards, ethnic traditions of a community, the type of situation (official/non-official), the form of apology (written/oral), social relations of the speaker and the hearer (the degree of familiarity), the speaker's feelings and the degree of the speaker's responsibility for what has happened.

\section{The Art of the Apology}

Admitting you are wrong is never easy, but at some point in our lives everyone has to do it. A bad apology can strain relations with a friend, a colleague, or a family member. The problem is, most people do not have much practice with apologies, so when it comes time to make one they do not know what to say and when to say it. Stephen R. Covey (Covey, 1989) and other scholars suggest some important steps that may make it easier to apologize. They can be summarized as follows:

Step 1: Be a sincere person.

Step 2: Clear up confusion regarding the situation of apology.

Step 3: Be a calm person.

Step 4: Take responsibility for your actions.

Step 5: Be specific and do not exaggerate things.

Step 6: Explain.

Step 7: Show your regret.

Step 8: Repair the damage.

Step 9: Use good timing.

Be a sincere person. The most important part of apologizing is sounding sincere. Do not pretend to be sincere. Apologize if you really mean it, if you are sincerely sorry for what you did. Make eye contact with the person (it is expected in Western cultures) and choose your words carefully. If the person does not believe that you are truly sorry, they will be angered that you tried to fool them with a meaningless apology. An insincere apology will only lead to further disingenuous interaction and dishonesty. Another important part of sounding sincere is to know why you are apologizing. State the reason why you are apologizing directly.

Clear up confusion regarding the situation of apology. If you actually do not understand what happened and just have a vague feeling that an apology is required because the other person is angry, do not just apologize to get it over with. Again, this just fosters a relationship of miscommunication. Instead, acknowledge that you are confused, that you want to understand, and then ask respectful questions about the other person's feelings. For example,

(39) I'm sorry I upset you so much. I'm not sure exactly what I did wrong, but I really want to understand so I can avoid doing it again. Will you help me?

Be a calm person. If you are still feeling resentful, defensive, or otherwise upset, wait until you feel calmer and more able to engage in honest, constructive conversation about whatever happened. Otherwise, the apology is likely to come out in a way unlikely to be helpful, and might possibly just make things worse. If possible, go off on your own somewhere until you are able to handle the situation calmly. 
Take responsibility for your actions. The first step in apologizing is to admit to yourself that you have offended someone. You may know this right away, or the other person's reaction may let you know you have done something hurtful. But you must admit you have done wrong and accept responsibility for your actions.

Talk about what YOU did, instead of adding on any qualifiers that blame the other person. Keep the apology itself as brief as possible, remaining focused on your own behaviour. Unless absolutely necessary, do not qualify your apology with references to the other person's behaviour. Consider the following examples:

(40) I'm sorry I was being so impatient with you;

(41) I'm sorry I was being impatient with you when you were being so indecisive.

In Example 41, the words you were being so indecisive are actually an attack on the person to whom you are supposedly apologizing, and they are (consciously or unconsciously) an attempt to abdicate responsibility for your own action by blaming the interlocutor. Also, they will often cause the other person to become defensive and less likely to listen to you, as they feel (quite rightly) that they are being subtly blamed.

On the other hand, if you take too much responsibility ("It's all my fault!"), then you start either 1) leaning toward the self-pity situation that pressures the other person to comfort you or 2) fostering an unhealthy relationship in which the other person has no need to take responsibility for anything.

Be specific and do not exaggerate things. Avoid hyperbole, exaggeration, self-pity, and vagueness. Instead, try to focus on a realistic and specific approximation of what you actually did wrong. For example: (42) I'm sorry I lost my temper in front of your colleagues; (43) I'm sorry I wasn't communicating with you very well about how I was feeling.

Exaggerations and vague generalizations put the other person in the position of defending you instead of accepting an apology, which is not fair to them. It is a way of (consciously or unconsciously) weaseling out of actually taking responsibility for your actions. Consider the following examples:

(44) I'm sorry I ruined our whole day. (exaggeration)

(45) I'm sorry. I just suck at this stuff. (self-pity)

These kinds of pseudo-apologies often work to inspire in a caring person the desire to comfort you, to say that it is really not all that bad, etc.

Explain. It is important to let the person you hurt know that you did not mean to do harm. At the same time, you must show that you take your mistake seriously. Recognize that your actions caused a problem for the other person.

When apologizing for something which the hearer does not yet know about or may not remember, the speaker needs to explain what has happened or remind the hearer of the situation. It is usual to add an explanation, excuse, offer of help, etc.: (46) John, about the meeting. I'm sorry I was late - I missed the bus; (47) I really must apologize for my behaviour last night. I'm afraid I was in rather a bad mood (Slovar sovremennogo angliyskogo yazyka, 1992: 39).

An excuse is the reason for the apology, which may or may not be true (Redman, 1997: 50). Here are some common excuses: (48) I'm sorry I'm late but I was delayed/held up at the airport; (49) I'm sorry I'm late but my train was cancelled. 
(= the train was timetabled but it did not run). To be/get delayed or be/get held up both mean to be late because of a problem that is out of your control.

Show your regret. The other person needs to see that you have suffered, too. Come right out and say you are sorry or ashamed. For example: (50) I felt bad the minute I told your secret. I'm ashamed of myself; (51) I feel dreadful about what I said on the phone. I didn't really mean it, you know (Slovar sovremennogo angliyskogo yazyka, 1992: 39). In Examples 50 and 51, we see that it is not always necessary to use any direct words of apology.

Repair the damage. To be complete, an apology must correct the injury. If you are responsible for a problem, you can offer or promise to do something about it. For example, (52) I'm sorry about the mess in here. I'll clear it up. (= I'll tidy it up); (53) I'm sorry about the confusion, but I'll sort it out. (= I will solve the problems) (Redman, 1997: 50); (54) I've got something awful to tell you. I lost that book you lent me. I'm really sorry. I'll buy you another (Slovar sovremennogo angliyskogo yazyka, 1992: 39).

If you damaged someone's property, offer to fix it. If the damage is not so obvious, ask What can I do to make it up to you? There may be nothing concrete you can do, but the offer must be sincere: (55) I'll try to keep my mouth shut in the future. Meantime, let me buy you a cup of coffee. Another way to repair the damage is to send a note or a small gift.

Use good timing. Remember that when it comes to apologizing, the sooner the better. The longer you wait, the worse it will be for both parties. The offended party may have grown angrier since the incident and might wonder why you did not apologize sooner. A late apology can be a humbling experience for the person apologizing because it seems as if he/she was the first to break down and admit wrongdoing. It is better to just apologize and be done with it.

Apologize right away for little things. For example, if you bump into someone, say you are sorry right away. Do not wait until the next day to apologize. When someone apologizes for something small the following quick apologies are used: (I'm) sorry. Excuse me. (AmE) Pardon me. (AmE) I beg your pardon. (fml) (Slovar sovremennogo angliyskogo yazyka, 1992: 38).

However, if you have done something more serious, like insult a friend, spilling coffee all over his/her new clothes, your apology should be more thoughtful. A quick apology might seem phony. Take the time to sit down, look the person in the eye, and apologize honestly. It is usual to add a comment:

(56) (Oh) I'm sorry. I didn't see you sitting there. (explanation/excuse)

(57) (Oh) I'm sorry. Are you all right? (expression of concern)

(58) (Oh) I'm sorry. I'll fetch some water. (offer of help)

(59) (Oh) I'm sorry. That was really clumsy of me. (self-criticism)

It is also possible to add words to make the apology stronger: (60) I'm very/really/awfully/so/terribly (BrE) sorry. For example, (61) I'm terribly sorry, I shouldn't have said that; (62) I'm so sorry, John - I didn't realize that was your boss; (63) I do beg your pardon. (BrE fml) It's not about who "won" or who "lost". It is about keeping a strong friendship.

Next, always try to apologize in person. An apology over the phone, or worse, an email apology, is impersonal. Make apologizing in person one of your top priorities so the person knows it is important to you. There are a few exceptions to this rule. If 
you live in a different city than the offended person, then the phone apology may be your only option. Also, if you are afraid the person might get angry, it is better to apologize by phone.

\section{Accepting an Apology}

When people apologize to us, it is very common to say something to reassure them (= tell them that 'everything is OK'), and that we are not angry (Redman, 1997: 50). We can say: It's all right, It's quite all right, No harm done, No need to be sorry, Forget it, Please don't worry, That's OK, No problem, Never mind, It doesn't matter (Formanovskaya \& Shevtsova, 1990: 50-51). For example,

(64) - I'm sorry I'm late.

- That's OK. Don't worry.

The most common response to an apology is something along the lines of "That's okay". Often this response is a lie. When it comes to apologies and responses to them, there are no good stock answers you can just trot out whenever necessary, because both should be tailored to the specific situation for optimal communication and benefit. Do not ignore the apology, and do not brush it off. If you are still angry, ask to continue the discussion after an hour (or whatever period of time seems best). Wait until you can listen calmly and respond constructively.

When someone makes an apology, the most constructive response is one that addresses the actual content of the apology. As with the apology itself, the response should be sincere, calm, and specific. For example,

(65) - I'm sorry I was being so impatient with you.

- I know I was being indecisive. It seemed like you were getting really frustrated with me.

Say and ask things that encourage the other person to tell you how they were feeling, why they behaved as they did, how you might both understand each other better in the future. Avoid comments that cut off discussion: (66) Yeah, well, you always do things like this; (67) I wish you'd stop always trying to make it all about you; (68) Fine. I forgive you.

Basically, what these sorts of responses really say is, "I don't want to understand this better. I just want you to shut up about it." While you might feel that way sometimes, it is not a healthy way to behave in a relationship, regardless of whether it is with a romantic partner, a family member, a work associate, or a friend.

Apology and forgiveness are two sides of the same emotional coin. Without apology and forgiveness, people remain locked in the value systems that produced the conflict.

\section{Apology as a Speech Act}

There are a lot of things we can do with words. We can make requests, ask questions, give orders, make promises, give thanks, offer apologies, and so on. Moreover, almost any speech act is really the performance of several acts at once, 
distinguished by different aspects of the speaker's intention: there is the act of saying something, what one does in saying it, such as requesting or promising, and how one is trying to affect one's audience.

The theory of speech acts, despite its more than six decades' history and multifold criticism remains a crucial element of linguistic research. In general, speech acts are acts of communication (Batsevych, 2004; Klyuev, 2002; RadevychVynnytskyi, 2001). To communicate is to express a certain attitude, and the type of speech act being performed corresponds to the type of attitude being expressed. For example, a statement expresses a belief, a request expresses a desire, and an apology expresses a regret. Performing a speech act, in particular an illocutionary act, is a matter of having a certain communicative intention in uttering certain words. One must choose one's words in such a way that their utterance makes one's intention recognizable under the circumstances. Such an act succeeds, if the audience recognizes that intention and identifies, in accordance with the speaker's intention, the attitude being expressed.

Taking into account mentioned above we are going to consider how apology can be realized on the examples of real speech acts. If you utter ' (I'm) sorry I didn't call back' and intend this as an apology, you are expressing regret for something, in this case for not returning a phone call. An apology is the act of (verbally) expressing regret for, and thereby acknowledging, something one did that might have harmed or at least bothered the hearer. An apology is communicative because it is intended to be taken as expressing a certain attitude, in this case regret (Ratmayr, 2003). It succeeds as such if it is so taken. In general, an act of communication succeeds if it is taken as intended. That is, it must be understood. With an apology, this is a matter of the addressee recognizing the speaker's intention to be expressing regret for some deed or omission. Using the performative 'I apologize' (Ivanova, Burlakova, and Pocheptsov, 1981) may facilitate understanding (understanding is correlative with communicating), but in general this is unnecessary. Communicative success is achieved if the speaker chooses his/her words in such a way that the hearer will, under the circumstances of utterance, recognize his/her communicative intention. So, for example, if you spill some water on someone and say 'Oops' in the right way, your utterance will be taken as an apology for what you did.

In saying something one generally intends more than just to communicate getting oneself understood is intended to produce some effect on the listener. When one apologizes, for example, one may intend not merely to express regret but also to seek forgiveness. Seeking forgiveness is distinct from apologizing, even though one utterance is the performance of an act of both types. As an apology, the utterance succeeds if it is taken as expressing regret for the deed in question; as an act of seeking forgiveness, it succeeds if forgiveness is thereby obtained.

Speech acts, being perlocutionary as well as illocutionary, generally have some ulterior purpose, but they are distinguished primarily by their illocutionary type, such as asserting, requesting, promising and apologizing, which in turn are distinguished by the type of attitude expressed. The perlocutionary act is a matter of trying to get the hearer to form some correlative attitude and in some cases to act in a certain way. For example, a statement expresses a belief and normally has the further purpose of getting the addressee form the same belief. A request expresses a desire for the 
addressee to do a certain thing and normally aims for the addressee to intend to and, indeed, actually do that thing. A promise expresses the speaker's firm intention to do something, together with the belief that by his/her utterance he/she is obligated to do it, and normally aims further for the addressee to expect, and to feel entitled to expect, the speaker to do it.

Statements, requests, promises and apologies are examples of the four major categories of communicative illocutionary acts: constatives, directives, commissives, and acknowledgments. This is the nomenclature used by Kent Bach and Michael Harnish (Bach and Harnish, 1980), who develop a detailed taxonomy in which each type of illocutionary act is individuated by the type of attitude expressed (in some cases there are constraints on the content as well). There is no generally accepted terminology here, and Bach and Harnish borrow the terms constative and commissive from Austin and directive from Searle. They adopt the term acknowledgment, over Austin's behabitive and Searle's expressive, for apologies, greetings, congratulations etc., which express an attitude regarding the hearer that is occasioned by some event that is thereby being acknowledged, often in satisfaction of a social expectation.

Speech Act theory, developed by Searle's following Austin's work, is based on the idea that language is a form of behaviour, and it is governed by rules (Searle, 1976: 22). Linguistic communication is seen as conventionalized, its minimal unit being the speech act, i.e. "an utterance that serves a function in communication". The idea that language is behaviour is the key to understand how language functions in a social context. As Anna Trosborg (Trosborg, 1987: 147) notes, "appropriate social behavior patterns, as they are perceived in Western societies, are built on the norms which constitute polite behavior". It is well known that what is considered as polite behaviour varies among different socio-cultural groups. Therefore, those norms which constitute polite behaviour will be different in different societies. However, in all social groups, an apology is called for when social norms have been violated, whether the offence is real or potential (Olshtain \& Cohen, 1983: 20).

A suitable definition of an apology for this study, dealing with post-event apologies, is the following: a compensatory action for an offence committed by the speaker which has affected the hearer. The speaker recognizes the fact that a violation of a social norm has been committed and that the speaker is involved in its cause. The involvement means a loss of face (= face threatening) for the speaker and is hearersupportive. Erving Goffman (Goffman, 1971) views apologies as remedial interchanges (i.e. remedial work which aims at re-establishing social harmony after a real or virtual offence has been performed), and makes a distinction between 1) apologies which redress a virtual offence, often realized by an apologetic formula (e.g. "Excuse me"), and 2) those which redress real damage on the addressee, which apart from an apologetic formula might also require an offer of material compensation (e.g. (69) “I'm sorry. I promise I'll fix it").

According to Goffman (Goffman, 1971), a full apology contains the following: an expression of embarrassment and chagrin; clarification that one knows what conduct had been expected and sympathizes with the application of negative sanction; verbal reflection, repudiation, and disavowal of the wrong way of behaving along with vilification of the self that so behaved; espousal of the right way and an avowal 
henceforth to pursue that course; performance of penance and the volunteering of restitution.

Whereas classical speech act theory classified apologies "according to felicity conditions for [their] most prototypical (or so it seemed) realizations" (Suszczynska, 1999: 1053), later pragmatic studies on apologies (Fraser, 1981; Olshtain \& Cohen, 1983) has provided natural data, which has allowed to define apologies as cultural-sensitive "speech act set" (Olshtain \& Cohen, 1983) "of semantic formulae or strategies found to regularly co-occur in apologetic responses, being relevant for a felicitous performance of this speech act" (Suszczynska, 1999: 1053). All these things considered, the act of apologizing requires an action or an utterance that is intended to "set things right" between the apologizer and the recipient of the apology. By apologizing, the person who committed the offence lets the offended person know that he/she is sorry for what he/she has done (Edmondson, 1981).

Different pragmatic researchers have examined apologies in different languages (e.g. (Radevych-Vynnytskyi, 2001; Shumiatska, 2013)) according to different variables: politeness strategies employed (e.g. (Bach \& Harnish, 1980)), cultural values reflected in the apology realization (e.g. (Suszczynska, 1999)), factors affecting the choice/use of a particular strategy (e.g. (Fraser, 1981; Olshtain \& Cohen, 1983), strategies used by native and non-native speakers (Trosborg, 1987), and others.

\section{Apology Strategies}

To our mind one point which is necessary to study is the classification of apology strategies. Following a model, built on Olshtain and Cohen (Olshtain \& Cohen, 1983), this classification of strategies is the following:

1. Illocutionary force indicating device:

The explicit illocutionary force indicating device is a formulaic expression which has the function of signaling regret on the speaker's part for the violation (that caused the apology), in order to conciliate the hearer. The examples of illocutionary force indicating devices are: "Excuse me, forgive me, pardon me; I beg your pardon, I apologize; I'm sorry”, etc. The illocutionary force indicating device and the other apology strategies are not exclusive. Thus, we can obtain an apology performed by one of the strategies, or a combination or sequence of them:

a) expression of regret: I'm sorry...

b) offer of apology: I apologize for ..., I offer my apology for...

c) request for forgiveness: Excuse me..., Forgive me..., Pardon me.

2. Acknowledgement of responsibility.

When the apologizer takes on responsibility, he/she tries to placate the hearer for the offence which created the need to apologize. On acknowledging responsibility, the apologizer can do so with varying degrees of self-blame (Trosborg, 1987: 150), and recognize his/her responsibility through a number of sub-strategies: a) explicit self-blame (The apologizer explicitly acknowledges that he/she has been at fault); b) lack of intent (The speaker explicitly states that he/she had not intended to hurt the hearer through his/her offence. The apologizer explicitly expresses that the offence was non-intentional and in so doing mitigates the offence); c) justify hearer (The apologizer communicates to the hearer 
that he/she fully understands the latter's reactions to the offence inflicted upon him/her); d) expression of embarrassment (the apologizer is acknowledging responsibility by expressing self-deficiency); e) admission of facts (The speaker openly accepts his/her involvement in the offensive act); f) expression of self-deficiency (The apologizer expresses (awareness of) his/her own deficiency, that has caused the offence).

The degree of acknowledgement of responsibility can be different. The highest level of intensity is an acceptance of the blame: "It's my fault". At a somewhat lower level would be an expression of self-deficiency: "I was confused/I didn't see/You are right". At a still lower level would be the expression of lack of intent: "I didn't mean to". Lower still would be an implicit expression of responsibility: "I was sure I had given you the right directions". Finally, the apologizer may not accept the blame at all: "It wasn't my fault", or he/she can even blame the hearer: "It's your own fault".

3. Explanation or account (An apologizer may mitigate his/her guilt "by giving an explanation or account of the situation" (Trosborg, 1987: 151)).

4. Offer of Repair (The apologizer may offer to 'repair' the damage which has resulted from his/her infraction. Repair may be offered in its literal sense or as an offer to compensate for the harm, the latter being relevant in situations in which actual repair is not possible or not wanted (Trosborg, 1987: 152).

5. Promise of forbearance (The speaker's sense of guilt may lead him/her to feel the need to promise that the act will never occur again).

In addition to the choice of strategies, the speaker can also modify these strategies using intensifiers, e.g.: I'm dreadfully sorry; I really am sorry, etc.

The above mentioned five major strategies are available to speakers, yet preference for any one of them or for a combination of them depends on the specific situation within the given language and culture group. The speaker's decision to choose an apology strategy is influenced by social factors: social distance (i.e., familiarity), social power (i.e., relative status), gender and age of participants. Moreover, there are contextual factors also involved: situational features such as the severity of the offence and the obligation of the speaker to apologize. In sincere apologies speakers often add an explicit expression of responsibility.

\section{Conclusion}

The apology belongs to the post-event-acts, i.e. it signals that a certain type of event has already taken place. Apologies actually consist of a set of routinized strategies. First, the speaker uses a word, expression, or sentence containing a verb such as "sorry", "excuse", "forgive", or "apologize". An expression of an apology can be intensified whenever the apologizer feels the need to do so. Such intensification is usually accomplished by adding intensifiers such as really, very, dreadfully, etc. Second, the offender recognizes his/her fault in causing the infraction. Third, the speaker describes the situation which caused him/her to commit the offense and which is used by this speaker as an indirect way of apologizing. The explanation is intended to set things right. Fourth, the apologizer makes a bid to carry out an action or provide payment for some kind of damage resulting from his/her infraction. Fifth, the apologizer commits himself/herself to not having the offense happen again. 
Knowing how to modify apology strategies in a given situation is as important as knowing which strategies to use when. Factors that may affect delivering an apology include: familiarity with the person being apologized to (intimate to very formal), the intensity of the act (its gravity, seriousness, or importance), the authority that each of the speakers has, their age, sex and the place where the exchange takes place.

\section{References}

Bach, Kent. and Harnish, Robert M. 1980. Linguistic Communication and Speech Acts. Cambridge, Mass.: MIT Press.

Batsevych, Floriy. 2004. Osnovy komunikatyvnoyi linhvistyky. Kyiv: Akademiya.

Brown, Penelope, and Levinson, Stephen. 1978. "Social Structure, Groups and Interaction." In Social Markers in Speech, 291-347. Cambridge: Cambridge University Press.

Cambridge International Dictionary of English. 1995. Cambridge: Cambridge University Press.

Covey, Stephen R. 1989. The 7 Habits of Highly Effective People. New York: Simon and Schuster/Fireside.

Edmondson, Willis J. 1981. “On Saying You're Sorry.” Conversational Routine, 273-288. The Hague-Paris: Mouton.

Formanovskaya, Natalia, and Shevtsova, Svetlana. 1990. Rechevoy etiket. Russko-angliyskiye sootvetstviya: Spravochnik. Moscow: Vysshaya shkola.

Fraser, Bruce. 1981. “On Apologizing.” Conversational Routine, 259-273. The Hague- Paris: Mouton.

Goffman, Erving. 1971. Relations in Public: Microstudies of the Public Order. Harmondsworth: Penguin.

Ivanova, Iryna, Burlakova, Varvara, and Pocheptsov, Georgii. 1981. Teoreticheskaya grammatika angliyskogo yazyka. Moscow: Vysshaya shkola.

Klyuyev, Yevgeniy. 2002. Rechevaya kommunikatsiya. Moscow: RIPOL KLASSIK.

Leech, Geoffrey, and Svartvik, Yan. 1983. Kommunikativnaya grammatika angliyskogo yazyka. Moscow: Prosveshcheniye.

Longman Language Activator. The World's First Production Dictionary. 1996. Harlow: Clays Ltd, St. Ives plc.

Macmillan English Dictionary for Advanced Learners. International Student Edition. 2004. London: Bloomsbury Publishing Plc.

Cohen, Andrew D., and Olshtain, Elite. 1983. "Apology: A Speech-Act Set.” Sociolinguistics and Language Acquisition, 18-35. Rowley, Mass.: Newbury House Publishers.

Radevych-Vynnytskyy, Yaroslav. 2001. Etyket i kultura spilkuvannya. Lviv: SPOLOM.

Ratmayr, Renate. 2003. Pragmatika izvineniya: Sravnitelnoye issledovaniye na materiale russkogo yazyka i russkoy kultury. Translated by Ye. Aralova. Moscow: Yazyki slavyanskoy kultury.

Razinkina, Nina. 2004. Standartnyye frazy povsednevnogo obshcheniya: Russko-angliyskiye sootvetstviya. Moscow: OOO Izdatelstvo Astrel.

Redman, Stuart. 1997. English Vocabulary in Use: Pre-intermediate and Intermediate. Cambridge: Cambridge University Press.

Searle, John R. 1976. “A Classification of Illocutionary Acts." Language in Society 8(1): 1-23.

Shumyatska, Oleksandra. 2013. "Zasoby realizatsiyi vybachennya v suchasniy nimetskiy movi." Inozemna filolohiya 125: 44-49.

Slovar sovremennogo angliyskogo yazyka in 2 volumes (A-L). 1992. Moscow: Russkiy yazyk.

Slovar sovremennogo angliyskogo yazyka in 2 volumes (M-Z). 1992. Moscow: Russkiy yazyk.

Suszczyńska, Małgorzata. 1999. "Apologizing in English, Polish and Hungarian: Different languages, different strategies." Journal of Pragmatics 31(8): 1053-1065.

Swan, Michael. 1997. Practical English Usage. Oxford: Oxford University Press. $147-167$.

Trosborg, Anna. 1987. "Apology Strategies in Natives/Non-natives." Journal of Pragmatics 11: 